\title{
The 10th China-Japan-Korea Joint Conference on Geography \& the 1st Asian Conference on Geography convenes in Shanghai, China
}

The 10th China-Japan-Korea Joint Conference on Geography \& the 1st Asian Conference on Geography was held in East China Normal University in Shanghai, China from October 9-12, 2015. The theme of the conference was "Urbanizing Asia: Diversity versus Globalization”. It attracted 318 geographic professionals from 8 Asian countries, including China, Japan, Korea, India, Mongolia, Pakistan, Nepal, and Laos, as well as western countries such as the United States, Sweden, and the United Kingdom. They were gathered in Shanghai to focus on the urbanizing Asia. Nearly 10 years after the first China-Japan-Korea Joint Conference on Geography hosted by The Geographical Society of China (GSC) in 2006, this conference has become a broader platform for academic exchanges for Asian geographers. The conference was co-sponsored by GSC, the Association of Japanese Geographers (AJG), and the Korean Geographical Society (KGS), organized by School of Geographic Sciences of East China Normal University (ECNU), and co-organized by The Geographical Society of Shanghai, Institute of Estuarine and Coastal Research (ECNU), School of Urban and Regional Sciences (ECNU), Key Laboratory of Watershed Geographic Sciences (Nanjing Institute of Geography and Limnology, Chinese Academy of Sciences), Key Laboratory of Virtual Geographical Environment (Nanjing Normal University, Ministry of Education), Key Laboratory of Beibu Gulf Environment Change and Resources Use (Guangxi Teachers Education University, Ministry of Education), and Beijing Laboratory of Water Resources Security (Capital Normal University).

Some distinguished participants included Prof. Bojie FU (President of GSC, Academician of Chinese Academy of Sciences, China), Prof. Yoshio ARAI (President of AJG, University of Tokyo, Japan), Prof. Bo-Kyung YANG (President of KGS, Sungshin Woman's University, Korea), Prof. Woo-Ik YU (Former Vice President/Secretary-General of IGU, Former Minister of Korean Unification Ministry, Former Korea Ambassador to China, Seoul National University, Korea), Prof. Yukio HIMIYAMA (Vice President of IGU, Hokkaido University of Education, Japan), Prof. Ram Babu SINGH (Vice President of IGU, University of Delhi, India), Prof. Batjav BATBUYAN (Director of the Institute of Geography, Mongolian Academy of Sciences, Mongolia), Prof. Prem Sagar CHAPAGAIN (Central Department of Geography, Tribhuvan University, Nepal), Prof. Kajsa ELLEGARD (Linkoping University, Sweden), Prof, Noritaka YAGASAKI (Former President of AJG, Nihon University, Japan), Prof. Lizhong YU (Vice President of GSC, Chancellor of Shanghai New York University, 
China) attended the conference.

The opening ceremony of the conference was held at the Science Hall of ECNU on the afternoon of 9th October which was chaired by Prof. Lizhong YU. Prof. Qun CHEN, President of ECNU introduced the history of ECNU and its contribution to geography, personnel training and services to the community in his welcoming speech to the participants. Prof. Bojie FU, on behalf of GSC, described the background of the conference, and pointed out China's current major trends in the community of geography, i.e., "One D, Two Es". "One D" denoted "deepen", suggesting that we should continue to deepen the basic research in geography, and strengthen the self-identity of geography as an independent discipline. "Two Es" represented "expand" and "extend", suggesting that we should, on the one hand, expand the research vision of geography, integrate cognate disciplines and fields into our research agenda, and give full play to the "comprehensiveness" of geography, and on the other hand, we must expand international cooperation and establish long-term academic partnerships with interested individuals and organizations, to shape our future Asia and the future planet. Prof. Ram Babu SINGH introduced the development of India's geography, and shared the research areas of the Indian geographers. Prof. Bo-Kyung YANG, Prof. Kenta YAMAMOTO (on behalf of AJG), Prof. Batjav BATBUYAN and Prof. Prem Sagar CHAPAGAIN also delivered speeches. Prof. Ramiz MAMMADOV (President of Azerbaijan Geographical Society), Prof. Abdul GHAFFAR (President of Pakistan Geographical Association), and Prof. Kanat BAIGARIN (President of Kazakhstan National Geographic Society) sent written speeches introducing the development and achievements of geography in their countries, and expressed their willingness to promote the development of geography together with the rest of Asian countries.

During the conference, Prof. Woo-Ik YU, Prof. Yoshio ARAI, Prof. Weidong LIU, Prof. Ram Babu SINGH and Prof. Yuemin NING were invited to make keynote speeches, respectively. Prof. Min LIU, Secretary-General of The Geographical Society of Shanghai and Prof. Yukio HIMIYAMA chaired these sessions.

There were 25 parallel sessions on the afternoon of October 10th and the morning of 11th. Nearly 100 presentations in 18 topics, such as population and urbanization, process of transformation in large cities, the sustainable development of cities and urban ecology, urban culture and economy, low carbon cities and climate change, urban pollution and human health, simulation prevention of urban disaster and risk estimates, city emergency systems and urban governance, etc., were delivered.

In addition, The 1st Asian Conference also pioneered 2 special units - "Women in Geography" and "Youth Gala". The purpose of creating Women in Geography was to investigate the issues and challenges that women geographers might encounter on their road to success and the corresponding coping strategies, to help women scholars grow. Youth Gala was intended to provide a young, fashionable, and fun way to let Asian geographers gather together and enjoy cultural diversities of different countries beyond academic exchanges, and to get closer and more intimate.

The conference successfully concluded on the afternoon of October 11th. Prof. Guoyou ZHANG, Vice President \& Executive Director of GSC, reviewed and evaluated the achievements of the conference in his closing remarks, and expressed sincere gratitude to the 
participants and the support of AJG and KGS. He emphasized that, The Asian Conference on Geography would be a new platform of academic exchange for all Asian geographers. He hoped that this platform will contribute to Asian and the world's geography. He said that, according to the suggestions of the experts, GSC would like to promote the building of Asian geography organizations. Prof. Jun WANG (Vice Dean of School of Geographic Sciences of ECNU) hosted the awarding ceremony of the conference. The conference presented Best Poster Award, Best Presentation Award, and Best Paper Award. A total of 20 representatives received these awards. Then, Prof. Min LIU delivered an affectionate speech, on behalf of the Organizing Committee, to express his gratitude to all scholars and students participating in the events, and thanked for the guidance and support from GSC, AJG and KGS, as well as the volunteers devoting for the conference. Finally, Prof. Sasaki TORU and Prof. Hitoshi ARAKI invited the guests in attendance to meet again in Hokkaido 2016.

As mentioned in the opening speech of Prof. Bojie Fu, more people are getting aware of the role of geographic sciences in government decision-making and social development. The geographers are also facing new opportunities and challenges. "One D, Two Es" is the common mission for both the Chinese geographers and the Asian geographers. Asian geographers should make good use of the Asian Conference on Geography to work together for shaping our future Asia and the planet!

During the conference, the 15th China National Young Geographers Symposium and Young Students Academic Debate, a business meeting of GSC Working Committee for Young Geographers, and China-Japan-Korea Geographical Societies business meeting were held simultaneously.

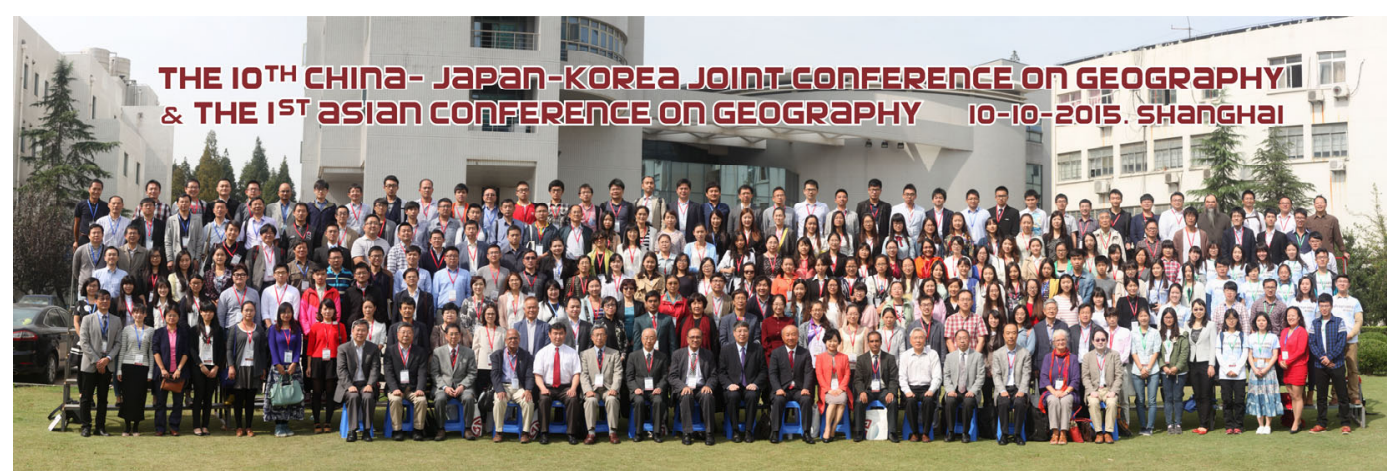

(Reported by the Geographical Society of China) 